\title{
STUDENTS' PERFORMANCE AT TUTORIAL ONLINE OF SOCIAL STUDIES THROUGH THE USE OF LEARNING CYCLE MODEL
}

\section{ABSTRACT}

\author{
Mohammad Imam FARISI \\ Faculty of Education, \\ Department of Social Studies \\ Universitas Terbuka, INDONESIA
}

The purpose of the study is to describe student's performance in tutorial online (tuton) of Social Studies through developing the 5Es - Engage Explore, Explain, Elaborate, and Evaluate- Learning Cycle Model (the 5Es-LCM). The study conducted at UT-Online portal uses the Research and Development (R\&D) method. The research subjects consisted of 21 UT's students from 16 UT's Regional Center (UPBJJ) in Indonesia. Data collected use the documentation and validation techniques and analyzed use the descriptivepercentage techniques. Qualitatively, student's performance is ' $/ o w$, viewed from their activities/participations in initiation, discussion, and ask-questions forums. Qualitatively, however, the quality of their performance is 'good', viewed from processes and contents of discussion and ask-questions; timeliness in the completion and scores of assignments; and competencies achieved. Some factors cause the low of students' performance in the tuton are the limited time for access, and technical factors.

Keywords: Student's performance, learning cycle model, tutorial online, social studies, universitas Terbuka.

\section{INTRODUCTION}

Some studies (Kadarko, 2000; Puspitasari \& Islam, 2003) report that Universitas Terbuka/UT (Indonesia Open University/IOU) student's learning performances are low to medium. It implied to their learning achievement, persistent; retention, and study completion. The most influential factors to those are personal psycho-social, learning support systems, and academic's environment are not conducive, less active and monologues (Darmayanti, 2002).An academic endeavor can be done to enhance student's learning performances is providing tutorial services, face-to-face or online. Conceptually, tutorial is an exposure form of the academic and pedagogical intervention model that can control of students learning systemically, and build a support system and academic's environment for student's independent learning process (Sugilar, 2000; Darmayanti, 2008; Darmayanti, et al., 2011). 
To create a high quality, conducive, active, and dialogues tutorial, every aspect of it should be well developed, such as organization, infrastructure, financial supports, human resources, and management (Adji \& Wahyuni, 2010). Design or model of tutorial is one of the important aspects that should be developed to improve student's learning performances; build their perception and attitude on learning; and develop their learning independent skill (Puspitasari \& Huda, 2000).

The purpose of the study is to develop materials of initiation, students' discussion and assignment in the tuton of social science education (PSOS4101) using five cycles of Learning Cycle Model (the 5Es-LCM)-Engage, Explore, Explain, Elaborate, and Evaluatein period 2013-2; and examine the effects of the model to the students' performances of learning activities and achievements. The model developed by Bybee et al. (2006) based on constructivist theory and pedagogy, and emphasis on the processes of scientific thinking and inquiry (Karplus, 2003).

This model is very suitable for social science education for developing student's critical thinking and inquiry skills, and student's skills in solving social realities and problems facing within the citizenship education context (NCSS, 2010). The study is expected to find an alternative solution to the Aprijani's et al., study (2009) found that tuton not been able to facilitate UT's student for enhancing their high-level thinking skills caused by subject's selection in the tuton is not precise.

The empirical studies on the 5Es-LCM are support to be used for across-subjects, natural science curriculum, and humanities. It has also proven effective in improving student's mastery of the subject matter; learning achievement and retention; student's positive concept, interest, and attitude to knowledge and learning; including to improve the 21st century learning skills (Bybee et al., 2006; Bybee, 2009). The model has furthermore been successfully developed by Huang et al. (2008; Liu et al., 2009) for a mobile learning to enhance student's learning achievement and their scientific performance, and to create ubiquitous learning environments, which cannot be provided in conventional learning environments. An integrating technology, including the Internet, into social studies learning are also supported by Martorella (1997). He asserts that "Arguably; technology is a sleeping giant in the social studies curriculum,...Technology and the social studies has the power to become a dynamic and forceful agent for change in the social studies curriculum" (p. 511). Some experts (Doolittle \& David, 2003; Ayas, 2006; Acikalin \& Duru, 2005; Acikalin, 2010) who have studied about the theoretical integration of technology in social studies agree that constructivism provides a theoretical, philosophical, and pedagogical foundation and principles for integrating technology into social studies. It is also potential to inspire new ways of learning and innovative learning, and strengthen the creation of constructivist classroom climate.

In fact, Diem (1983) found some immediate implications of micro-technological revolution to social studies, namely access to technology, information control, social responsibility, and social implications. 
Finally, Braun and Risinger (1999) review the results of research on the use of Internet technology in social studies, have concluded that the Internet provides a source and repository of ideas for social studies teachers in a number unmatched, unlimited, and far beyond the resources can be provided in a traditional curriculum. The Internet has also become an essential element of the repertoire of learning tools to engage learners in the study of social studies curriculum.

\section{METHOD}

The study uses the Research and Development (R\&D) method, which has been modified by Thiagarajan, Semmel and Semmel (1974) into four stages: Define, Design, Develop, and Disseminate (Four-D). The R\&D conducted in one year on the UT-Online portal (www.student.ut.ac.id).

Define stage is preliminary analyses involve five steps:

$>$ front-end analysis to identify major problems facing students in the tuton;

$>$ learner analysis to identify student's characteristics;

$>$ concept analysis to identify essential or basic concepts in social studies module;

$>$ task analysis to identify students active and assignments; and

$>$ specifying instructional objectives to identify the structure of social studies competencies.

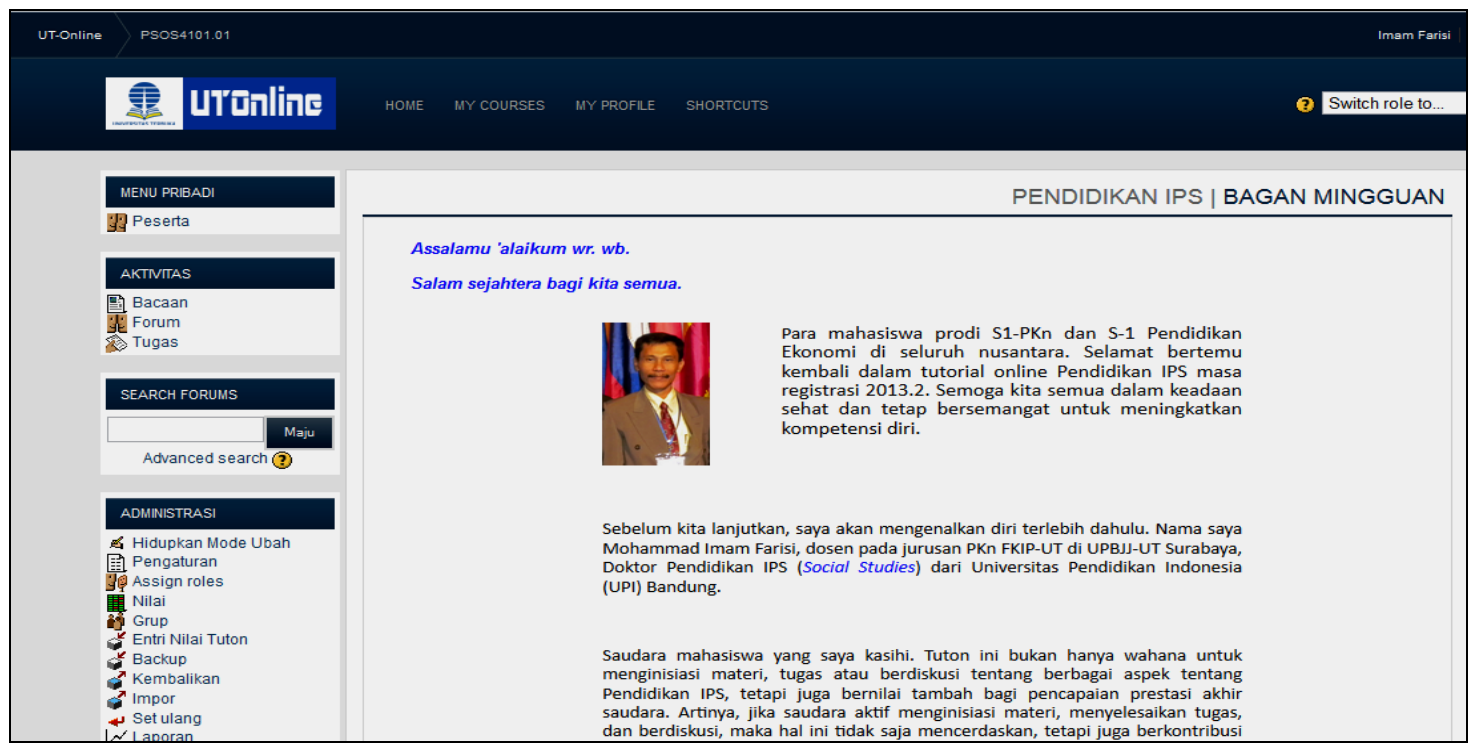

Figure: 1

UT-Online homepage on the UT' Website 
Design stage is design of the prototype tuton materials (PP-0) involve four steps:

$>$ construction of test/validation/evaluation sheets;

$>$ design of materials' format and contents of discussion and ask-question Forums;

$>$ design of initial products for presentation of tutorial through the Internet; and

$>$ selection of experts to test/validate/evaluate initial products.

Test/validation/evaluation sheets consist of:

$>$ expert test/validation sheets for six experts, three experts of instructional design, two experts of content, and an expert of evaluation/assessment.

$>$ student test/validation sheets for students/users who participate and use the products in the tuton.

$>$ expert evaluation sheets for the participants of the seminar.

Design of material's format uses the 5Es-LCM consists of engage, explore, explain, elaborate, and evaluate; and its contents chose of essential or basic concepts of social studies. Designs of prototype products consist of materials for initiation, students' activities and assignments for eight tuton episodes. Products designed based on the results of the define stage.

Develop stage is a modification of the prototype material through two steps: (1) expert appraisal for validating and obtaining suggestions for the improvement and revise of the initial products (PP-0) into PP-1, so it is ready for used by students in the tuton; (2) developmental testing for obtaining student's input-responses, reactions, commentaries-to the products for the improvement and revise of the products (PP-1) into PP-2.

Disseminate stage is summative evaluation. In the study, it conducted through a seminar to obtain expert inputs, corrections, suggestions, and evaluation from participants for finalizing the products. This is also intended to diffuse or disseminate of the products, so it was ready for adopted by users broadly. The research subjects consisted of 21 students at the UT department of social studies and participate actively in the tuton period 20132. They come from 16 UT's Regional Centers throughout Indonesia. Data for collecting and validating the products in every stage use the amount instruments such as: mapping sheets; experts and students' test/validation sheets; and expert evaluation sheets. Data for collecting student's performance using:

> students active and participation's track-record as documented at the UTOnline portal; and

$>$ the results of the student's assignments completion. Data then analyzed using a descriptive-percentage technique. 


\section{RESULTS}

\section{Tuton Design}

The tuton design of social studies with the 5Es-LCM consisted of designs of initiation materials, students' activities and assignments for eight tuton episodes.

The materials design for initiation developed on the base of general and specific competencies; and contents of social studies.

Initiation materials structure organized and developed in accordance with the syntax and structure of the 5Es-LCM.

The tuton activities designed into three student's activity or participation such as:

$>$ student's passive participation in opening and reading the initiation materials,

$>$ student's active participation in discussing topics prepared by the tutor; ask questions on problems faced in module or practice; share ideas, knowledge, problems and/or experiences to the peers in the Discussion or Ask-Question Forum; and

$>$ student's active participation in completing the assignments.

The tuton assignments designed and developed for three times of eight tutorial periods (third, fifth, and seventh), and aimed to test or examine a student's ability in mastering three social studies competencies:

$>$ competency in mastering the essential or basic concepts of social studies;

$>$ competency in solving the problems faced in the classroom practices using concepts, theories, or models who learned from the module; and

$>$ competency in applying or implementing concepts, theories, or models who learned from the module into social studies practices in the classroom.

The structure of the tuton assignments consists of:

$>$ specific competencies of social studies;

$>$ learning competencies to be assessed;

$>$ the tuton assignment types (essay, practice, or observation);

$>$ time for completion; and

$>$ references or learning resources.

Design Quality

The results of test or validation by six experts to the quality of initial product's design (PP-0) are "suitable" (100\%) to student's characteristics; social studies goals and competencies; the structure and content of the assignments and activities. 
Experts have also been judged that the quality of the tuton syntax is "good" $(65.56 \%)$ and "very good" (34.44\%); the quality of initiation and discussion materials is "good" or "very good" (50.00\%); and the qualities of the tuton assignments also are "good" $(87.50 \%)$ or "very good" (12.50\%). Experts state that all initial products design (PP-0) can be used safely in the the tuton.

However, experts recommend revising some aspects of prototype products:

$>$ the 5Es-LCM syntax should be stated clearly in introduction of initiation, activities, and assignment materials, so students understand the steps that must be performed easily.

$>$ Every step of the cycle should contain learning goal as a framework for a developer in organizing initiation, activities and assignment materials; and for students in following directions and instructions given in the materials.

$>$ Initiation, activities, and assignment materials should be enriched with exercises to motivate and encourage of students to improve their problemsolving skills and/or teaching performances in/out the tuton class.

The results of test or validation by 14 students/users to the quality of revised products design (PP-1) are "good" (49.4\%), "very good" (45.8\%). The others (17.9\%) appraise the content of initiations, assignments, and its ease in the use are "bad". According to students/users's appraisal, some content of initiations and assignments should be expanded, so they are easier to understand the contents of the module. They also suggest that the contents of assignments should be given a description on the context of the problems, so assignments can be understood, answered or solved easily.

Finally, the results of expert evaluation of 16 participants of the seminar to the six descriptors of products design quality (PP-1), generally are "good" (62.50\%), "very good" $(37.50 \%)$, and not a participant appraises that products are "bad." The results of participant's evaluation to six descriptors as follow:

$>$ the clarities of the products' information are "good" $(56.25 \%)$, and "very good" (43.75\%).

$>$ the validities of the products are "good" (68.75\%), and "very good" $(31.25 \%)$.

$>$ the pervasiveness of the products' information to all the audiences for students/users intended are "good" (75.00\%), "very good" $(25.00 \%)$.

$>$ the impact of the products to the student's learning achievements and performances are "good" (56.25\%), "very good" (43.75\%).

$>$ the timeliness in product's completion at the most opportune time is "good" (62.50\%), "very good" (37.50\%).

$>$ the practicality of the products in use considering such limitations as distance and available resources are "good" (62.50\%), "very good" $(37.50 \%)$. 


\section{Student's Performance}

Student's Participation

According to the student's profile record, there are 47 students registered as the participants of tuton for period 2013-2. However, is only $21(44.68 \%)$ students who follow or participate actively in the tuton. There are two factors cause they do not follow or participate in the tuton:

First, application of a 'passive system'. In the system, student's registration in tuton is not based on student's interest, willingness, and/or demand but on the courses who have been registered in the ongoing semester. It processed automatically by the system (UT, 2013). This system is related to UT's efforts for expanding student's opportunities to choose various modes of tutorial services provided; and to enhance the learning support services to all students, especially for the courses which face-to-face tutorial are not provided. As shown on student's profile, every student enrolled automatically for 6-7 courses. Of course, student may not be able to participate in the tuton for all courses registered fully. They will be difficult to arrange their time for access, with access duration are very limited. As reported by Sukarsih (2005), that students who register4-10 courses, only $0.7 \%$ to $2.1 \%$ who participated in the tuton fully.

Second, technical constraints are related to 'activation procedure'. In UT's procedure, every student who will enter to UT-Online portal and will participate in the tuton should do activation previously. It is important for identifying of membership one, and avoiding the 'anonymity' for anyone will be activities or participate in the UT-Online. One the one hand, this activation is a standard procedure prevailing on the portal as 'restricted area' especially for UT's students and academic members. On the other hand, the activation process brings the consequence that not all users had access to the portal, even if they listed as the tutor participants (Darmayanti, Setijani \& Oetojo, 2007).

The student's participation performance in the tuton can be classified into two categories:

$>$ passive participations is indicated by student's participations in opening and reading the initiation materials.

$>$ active participations are indicated by student's participations in:

- discussing topics prepared by the tutor; ask questions on problems facing in module or practice; share ideas, knowledge, problems and/or experiences to the peers through the Discussion or AskQuestion Forum; and completing the assignments.

- Student's active or passive participations analyzed by the time and number of their participation in the tuton.

The study shows that the times average of student's passive participation for every tuton period are $22-23(40.18 \%)$ of 56 effective days fully, with the maximum participation are 61 times. 
In fact, the study shows that the time and amount of student's passive participation in the tuton are fluctuating. The time of student's participation decrease down to $80 \%$, and the amount of students who participate decrease down to $50 \%$ from the first to eight periods (one period is seven days). Overall, students who 'very active' to open and read the initiation materials are $9(42.86 \%)$ persons, and who 'never" open and read the initiation materials are $5(23.8 \%)$ persons.

The times average of student's active participation for every tuton period is $5-6(9.82 \%)$ of 56 effective days fully, with the maximum participation is 16 times. The time and amount of student's active participation in the tuton are fluctuating, and it decreases down to $87.5 \%$. The amount of student's active participation also decreases down to $70 \%$ from the first to eight periods. The data also show that of all students who 'very active' in the Discussion and/or Ask-Question Forums are 3(14.28\%) persons, and who 'never" participate in the Discussion and/or Ask-Question Forums are $10(47.62 \%)$ persons.

The findings above shown that, the average time or amount of student's active participation in the tuton are lower than their passive participation. Overall, however, the time and amount of student's participation in the tuton are ' $/ o w$. Students tend to be 'a passive participant', both opening and reading initiation materials and/or in the Discussion and/or Ask-Question Forum. The findings are relevant with Afriani's study (2007), that state UT's students tend to 'participate passively' $(36.3 \%)$ in the tuton program.

According to Rafaeli, Ravid and Soroka (2004); Soroka and Rafaeli (2006), the passive participant phenomenon is an integral and a normal part of Internet behavior, especially in the online community forums, including the tuton. Their existence can be defined as ' $a$ persistent but silent audience', and indicated by activities '/ying in wait' or 'to persist in staying'.

Researchers predict that these phenomena are present en masse with percentages of passive participants estimated to be $50-90 \%$. They conclude that the passive participant phenomenon is a corrosive activity for developing and sustaining the forum. It has negative or harmful influences to student's efforts for obtaining a comprehensive understanding about contents and/or achieving competencies of the course.

It will also be influenced negatively to create a good interaction and communication among UT's students to share idea, knowledge, skill, experience, or expertise.In such condition, one of the ultimate functions and goals of the forum for building the UT student's learning community cannot be achieved (Hanafi, Julaeha, \& Noviyanti, 2008).

On the other hand, however, contents and interaction among students in the discussion and/or ask-question forum, quantitatively, is "good". The following quotations show it. 
Discussion Forum 1

Brother of students, the participants of the tuton. Based on the three

paradigms/traditions in social studies have been put forward in the first initiation material, please you try to discuss the following topics:

1. Where is a paradigm/tradition followed and developed in Indonesian social studies?

2. What and how the conceptual foundations of social studies according to the paradigm/tradition that followed and developed in Indonesian social studies?

MARSELENA 018526318 - Tuesday, September 3, 2013, 19:09

In my opinion, all of these traditions are worthy to be followed and developed in Indonesia, with all its advantages and/or disadvantages. Because, however, over time, like it or not, able or not able, as a great nation we must also adjust to the advancement of science and technology, with a note, we do not forget or rule out noble values of the nation who had noble morals and dignity...How do peers think about it?

DWI SURYENI 018299843 - Tuesday, September 3, 2013, 19:36

Yes, I agreed. However, at this time, many strange influences that make a person forget our culture, which has a noble character and dignity. For example, many young people in this age more love of imported cultures than our culture. Next, what do you think to overcome such problems?

NOVA LITA ARDIANA 017223273 - Wednesday, September 4, 2013, 14:45

In my opinion:

1. All traditions should be developed in our nation. We expect Indonesian people be able to maintain, preserve the history, values and culture. They expected also able to think, behave, and act disciplinary and based on the scientific methods. Thus, they become critical and reflective generation over a wide range of situations and problems facing our nation.

2. Conceptual foundation of social studies education is: provide a wide range of fundamental understanding; train various skills, and develop moral attitudes needed by our nation, and could develop social studies learning materials in order to answer the problems that often arise in the learning process, both in primary and secondary schools.

BINTI NIKMATUL MAULUDIYAH 016470865 - Thursday, September 5, 2013, 11:41

In my opinion, these three social studies traditions need to be developed in Indonesia, because the concept of Indonesian education emphasizes to the inheritance of historical knowledge, values, and culture of the past for nurturing and developing young people who able to maintain and preserve the history. Our educational concept also emphasizes the mastery of concepts, generalizations, and the scientific method of the social sciences for fostering and developing young generation able to think, act, and act disciplinary on the basis of the scientific method. It also emphasizes on the formation of the young people's ability to analyze and make decisions. 


\section{Assignment's Completion}

Student's performance in assignment's completion focused on three aspects:

$>$ amount of assignment's completion and submission to tutor;

$>$ timeliness of assignment's completion and submission to tutor; and

$>$ assignment's quality.

Quantitatively, the amount of assignment's completion and submission to tutor are 'lower'. Of 21 students who participated in the tuton, 8(38.09\%) students accomplish and submit 18 assignments to tutor. It consisted of $4(19.05 \%)$ three students accomplish and submit to tutor; 4(19.05\%) students accomplish and submit 1-2 assignments; and $13(61.90 \%)$ students never accomplish and submit their assignments to tutor. The same findings also reported by Afriani (2007), that of 15(51.7\%) students who participate actively in the tuton are only $8(27.6 \%)$ accomplish and submit their assignments to tutor. The timeliness of assignment's completion and submission is 'good. Of 18 assignments accomplished and submitted to tutor, 8(55.56\%) are on-time; $7(38.89 \%)$ are passing time; and $3(16.67 \%)$ are early time. Overall, the assignment's quality accomplished and submitted to tutor is "good," with a mean score 68.65. The score of the first assignment is 69.29; second assignment is 71.67; and third assignment is 65.00. According to UT' regulation, the assignment's scores are having a contribution about $30 \%$ to the final score of the course (UT, 2013).

\section{Competencies Achievement}

The results of assess of the three social studies competencies are 'good' with a mean score 68.89. The score of first competency (concept attainment) is 68.33; second competency (problem solving) is 67.78; and third competency (knowledge application) is 70.56. The competencies they achieved are not optimum. This is because a tutor cannot give guidances to students directly in inquiry processes who conducted. According to Martin-Hauser (2002) and (Windschitl, 2003), teacher's guidance for students to investigate and execute inquiry procedures to solve the problem is a key for their success in the 5Es-LCM. The students' lack of suitable resources and immediate learning supports when teachers and students are scattered in different locations are the other problems and constraints in the 5Es-LCM implementation online (Dillon et al., 2006).

However, the findings shown that the use of the 5Es-LCM in the tuton, can facilitate students to achieve ultimate goals of social studies, such as reflective inquiry, and master on the scientific structure of social sciences (Barr, Barth \& Shermis, 1977, 1978). It was also can facilitate students to develop scientific thinking skills or high-level thinking process, and develop problem-solving skills based on systems thinking patterns (Bybee et al., 2006; Bybee, 2009).

The findings shown also students more able to understand contents of the module related to knowledge (concepts, theories, or models) related to learning practices and problems facing in the classroom than are related to essential or basic concepts of social studies. 
Practically, it can be understood, because they are social studies teachers of junior or senior high school. They should be competent in managing classroom practice and in solving problems facing in the classroom.

However, they should also master of essential or basic concepts of social studies as an integrated scientific discipline. Theoretically, "Social studies is powerful when they are integrative" (NCSS, 2010). Therefore, student's mastery on integrated scientific methods and concepts is a fundamental element of social studies, so they could critical and reflective thinking, and solve problems, enigma, uncertainty, or anomaly in social live (Barr, Barth \& Shermis, 1977, 1978; Bammer, 2008).

Problems and Constraints

The study found two factors to cause student's participation is low:

$>$ limited time for access;

$>$ technical constraints.

Limited Time for Access

This factor is related to student's opportunity to access or participate in the tuton, while they should also completion their daily tasks as a teacher. It can be analyzed from:

$>$ student access, is the amount of student who accesses;

$>$ frequency of access, is many times student access;

$>$ duration of access, is the amount of access in a day, hour, or minute; and

$>$ time of access, is when student access (before, in, or after office hours).

\section{Student Access And Frequency Of Access}

Average of student who access the tuton is $11(54.42 \%)$ everyday or is $5(20.83 \%)$ every hour. Total frequency of access for all students is 244 times in eight periods of the tuton. Detail of access is $182(74.59 \%)$ times for passive participation, $44(18.03 \%)$ times for active participation, and $\mathbf{1 8}(7.38 \%)$ times for assignments. So, average of access for every student is $12(4.76 \%)$ times, and highest access is $37(15.16 \%)$ times.

\section{Duration of Access}

The tuton activities are 'oftentimes', where students can access it every time, every day, in or out of office hours. If assumed student access fully, they have 56 days or 9.408 hours. According to UT's tuton regulation, hopefully, every student access of the tuton as many as $\mathbf{1 0 0}$ hours in $\mathbf{5 6}$ days, or $\mathbf{1 . 7 8}$ hour every day. The study found, total days of access for all students are 131 days or every student is $6(11.14 \%)$ days of 56 days totally. Meanwhile, duration of access for all students is 218 hours in 56 days, and highest duration is $\mathbf{2 3}$ hours (three students).

This means; every student has a duration of access is 10.38 hours in $\mathbf{5 6}$ days or 0,18 hours every day. Based on the regulation, in fact, duration of student's access is 'very low', that is $10 \%$ of normal duration. 


\section{Time of Access}

The findings shown, students start to access tuton at 07:00 to 00:59 AM. Majority of students $(65.55 \%)$ access out of office days (Sunday) and out of office hours (14:00 PM-06:59 AM) every day. It consisted of $1.68 \%$ students are accesses before office hours (05:00-06:59 AM); 52.10\% students are accesses after office hours (14:00 PM00,59 AM); and 11.76\% students are accesses on Sunday (07:00 AM-21:59 PM). Meanwhile, students are accesses in the office days or hours are $34.45 \%$.

Based on four indicators above, the study shown that student's opportunity for access and participate in the tuton is very limited in terms of frequency, duration and time of access.

\section{Technical Constraints}

The study has identified three technical constraints, which have been influenced to the low of the student's performance to participate in the tuton. These factors are in terms of cost, facility, and network. Besides, it has also been caused the student's opportunity to access is very limited.

According to time of access, students tend to access the tuton out of office days (Sunday) and out of office hours (14:00 PM-06:59 AM) every day. Total of students who accesses are $65.54 \%$ with total access are $108(66.67 \%)$ times. It consisted of $52.10 \%$ students are accesses after office hours (14:00 PM-00:59 AM); 1.68\% students are accesses before office hours (01:00-06:59 AM); and 11.76\% students are accesses on Monday. However, students who access in office days and hours (Monday-Saturday, 07:00 AM-13.59 PM) too much (34.46\%) with a total of access are 54(33.33\%) times.Tendency for students to access the tuton out of office days are related to the 'accessing strategy to avoid network congestion or slow access.

The findings supported by a Sukarsih's study (2005) reports that $24.1 \%$ students access the tuton at night, dan $\mathbf{9 . 6 \%}$ students access the tuton at morning, before office hours. Andriani (2005) and Afriani (2007) also report that $41.6 \%-5 \%$ students who login into UT-Online requires a long time and difficult or failed to access the tuton. In relation with the study findings, Bandalaria (2003) sates that most common problems encountered by the online students are circumstantial problems are brought about by circumstances specific to the students like geographical location; and technical problems are related to hardware or software application.

Tendency for students to access the tuton in office days and hours are also related to 'mini-max financing and facility strategy to save or minimize cost and maximize office's facilities. For students, to access the tuton in office days and hours is very appropriate time of access strategy to save cost and maximize the existing office facilities. According to Speedy Wiki's reports (2011), Internet cost by a time-based or data-based counting system in Indonesia is IDR $\mathbf{5 0 . 0 0 0}$ every month for 24 hours access. If the average income per capita of the population of Indonesia is IRD 2.56 millions (US\$164.289), Internet cost should be paid is only $2.5 \%$. 
It actually is not too high, although according to UNDP-APDIP's reports (2011), the Internet cost is very high, even, Indonesia is 'highest" of the states in the world. This is because Internet penetration rate in Indonesia is 'low', that only $12.5 \%$ (Teo et.al. 2003). This condition is compounded by the average income per capita of the population of Indonesia is IRD 2.56 millions (US\$164.289) every month.

However, data also indicate that of the total family/household in Indonesia is only $15.69 \%$ of those who have a personal computer/PC/laptop in a year 2011 (BPS, 2012). On the other hand, currently, the National Education Department of the Republic Indonesia in cooperation with the communication network providers has developed the National Education Networks (Jardiknas) and Indonesia Digital School (Indischoo). It has been able to connecting 118.000 schools in Indonesia with broadband access (wifi@id) (Yoenianto, 2013). In such conditions, it can be understood if many of the students utilize the existing office facilities and access in office days and hours. Sukarsih's study (2005) reports that only $4.9 \%$ students use a personal computer (PC), and $38.6 \%$ students use office's computer networks to access the tuton. Afriani (2007) also reports that $\mathbf{1 6 . 7 \%}$ students access the tuton use their office's computer facilities.

\section{IMPLICATIONS}

Conceptually, UT as one of $\mathbf{1 0}$ mega universities in the world should have a competitive advantage in capacity and support systems in providing Internet-based learning services; and it should also able to reduce costs (cost-effectiveness) at the level of differentiation that can be compromised (Daniel, 1995). In fact, UT has been increased periodically the Internet connections capacity. In 2006, UT has the Internet connections capacity is 384 Kbps (Pokja TIK, 2006). Currently, it has been increased up to $100 \mathrm{Mbps}$ for international Internet connection, $1 \mathrm{Gbps}$ for local Internet connection with open ixp, and 15 Mbps with open iix for providing support systems to over $\mathbf{5 0 0 . 0 0 0 ~ s t u d e n t s ~ ( U T , ~}$ 2012). However, this seems not yet fully able to meet all the needs of the students' access, and can overcome of their network or access constraints. Therefore, since July 2013, UT has been launched free-charge Cloud Services Technology, 'Office 365 for Education", to all students and lecturers, in collaboration with Microsoft. It is intended to provide every student an email account with 50 GB capacity and documents storage up to 7 GB, so they may be able to communicate and interact with peers and/or tutor extensively. It has also been completed by SkyDrive Pro application, which allows the students to submit, save, revise document online, and share it to peers and/or tutors (UT, 2014).

In addition to the UT's innovative efforts above, some important aspects should be done forward to enhance students' performance in tuton, that are:

$>$ Continuing to boost the capacity of student's access in collaboration with local agencies in providing and facilitations limited time of access and ensuring the success of the student's learning process (Herman, 2013). Collaboration with the ICT-Centers is one of the alternatives for it. 
As reported by Daulay (2009) that the ICT-Centers as local agencies in providing and facilitations the Internet highly useful to support their studies at UT; especially to facilitate students who live in rural areas, where Internet access is extremely limited (Puspitasari, 2002). It also very important to be negotiated in the collaboration are giving the discount rate for the student to reduce the cost (Hanafi, et al., 2008).

$>$ Providing a psychological and academics intervention to students in before the scheduled time year of study. It is very important to introduce on distance education systems since early (Damayanti, 2008; Hanafi et al., 2008), and develop the skills of the distance learners to take advantage of the convergence of modern information and communication technologies (Bandalaria, 2003).

$>$ Getting ready for the tuton through: (a) training of faculty members (tutors) in designing the on-line course site; in acting as moderators of online discussions, the technical support group, and the learning center coordinators; (b) providing a conducive support and policy environment, include the provision of Internet allowance to on-line tutors who will be accessing their on-line course sites through the Internet cafes of their personal Internet accounts; (c) expanding the university research program includes monitoring, evaluation, and other research concerns with the end view of continuously for improving the tuton system; and (d) converging technology and pedagogy to ensure that the technology which be used appropriate with the pedagogical concerns (Bandalaria, 2003).

$>$ Designing the initiations, discussion/ask-question topics, and assignments' materials in an interesting and challenging format. It is very important to ensure students be interested and challenged to participate actively in the tuton; and anticipate the emergences of the lurking phenomenon (Soroka \& Rafaeli, 2006).

\section{CONCLUSIONS}

The study shown that student's performance in the social studies tuton is ' $/ o w$, viewed from their passive or active participations. However, it viewed from the quality of contents and interaction between of students in discussion and ask-question forums, assignment's completion, and competencies achieved; their performance is 'good. The low student's performance is caused by factors:

$>$ limited student's time for access; and

$>$ technical constraints in terms of the cost, facility, and network factors.

The study recommends; UT should:

continues to boost the capacity of student's access in collaboration with local agencies to provide and facilitate limited student's time of access, and ensure the success of the student's learning process; 
$>$ provides a psychological and academic intervention to students in early year of study to introduce on distance education systems, develop their skills to take advantage of the convergence of modern information and communication technologies;

$>$ trains of faculty members (tutors) in various aspects of distance student services;

$>$ provides a conducive support and policy environment to facilitate an effective tuton; (5) expands the university research program for improving the tuton system;

$>$ convergences, technology and pedagogy to ensure that the technology which be used appropriate with the pedagogical concerns; and

$>$ designs the initiation materials, discussion/ask-question topics, and/or assignments in an interesting and challenging format to get student's interest and challenge their participate actively in the tuton.

AUTHOR NOTE: Financial Support of the study has supported finance by the Directorate of Research and Community Service, Directorate General of Higher Education, the National Education Department of the Republic of Indonesia, under Letter of Duty No. 10264/UN31.2/PG/2013.

\section{BIODATA and CONTACT ADDRESSES of the AUTHOR}

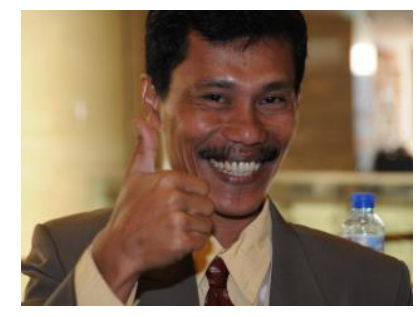

Mohammad Imam FARISI is a Lecturer in the Department of Social Studies, Faculty of Education at the Universitas Terbuka Indonesia (Indonesia Open University). He has completed his Doctor (Dr.) in Social Studies at Indonesia University of Education by scholarships from Directorate General of Higher Education, the National Education Department of the Republic of Indonesia. He has been published over $\mathbf{3 0}$ articles at National and International Journals; some books on education, and social studies. He has also presented academic papers at the National and International Conferences/Seminars on education, especially in Social Studies; and a trainer/human resource at professional workshops or trainings for teachers and tutors.

Mohammad Imam FARISI

Faculty of Education, Department of Social Studies

Universitas Terbuka-Surabaya Regional Office, INDONESIA

Office Address: Kampus C Universitas Airlangga, Mulyorejo

Surabaya 60115, INDONESIA

Phone: (+62-31) 5961861; (+62-31) 5961862;

fax: (+62-31) 5961860

Email: imamfarisi@ut.ac.id ; imamfarisi@yahoo.com 


\section{REFERENCES}

Acikalin, M. (2010). Exemplary social studies teachers use of computer-supported instruction in the classroom. The Turkish Online Journal of Educational TechnologyTOJET, 9(4), 66-82.

Acikalin, M., \& Duru, E. (2005). The use of computer technologies in the social studies classroom. The Turkish Online Journal of Educational Technology-TOJET, 4(2), 18-26.

Adji, S., \& Wahyuni, S. (2010). Model Pembelajaran Problem-Based Learning (PBL) pada Tutorial Online. Researh report. Jakarta: LPPM-UT.

Afriani. (2007). Analisis pemanfaatan tutorial online mata kuliah Writing 1. Jurnal Pendidikan Terbuka dan Jarak Jauh, 8(1), 15 -23.

Andriani, D. (2005). Mahasiswa S2 pada sistem pendidikan jarak jauh: Pemanfaatan internet dan bantuan belajar. Jurnal Pendidikan Terbuka dan Jarak Jauh, 6(2), 77-91.

Aprijani, D. A., et al. (2009). Analisis kualitas layanan sistem e-learning berbasis open source moodle dalam tutorial online di Universitas Terbuka. Research report. Jakarta: LPPM-UT.

Ayas, C. (2006). An examination of the relationship between the integration of technology into social studies and consructivist pedagogies. The Turkish Online Journal of Educational Technology-TOJET, 5(1), 14-25.

Bammer, G. (2008). The case for a new discipline of integration and implementation sciences i2s. Integration Insights, 6, 1-5.

Bandalaria, M. P. (2003). Shifting to online tutorial support system: A synthesis of experience. Jurnal Pendidikan Terbuka dan Jarak Jauh, 4(1), 32-41.

Barr, R. D., Barth, J.L., \& Shermis, S. S. (1977). Defining the Social Studies. Virginia: National Council for the Social Studies.

Barr, R. D., Barth, J. L., \& Shermis, S. S. (1978). The Nature of the Social Studies. Palm Spring CA: ETC Publications.

BPS. (2012). Perkembangan Beberapa Indikator Utama Sosial-Ekonomi Indonesia. Jakarta: Badan Pusat Statistik.

Braun, J. A., \& Risinger, C. F. (Eds). (1999). Surfing social studies: Thee intemet book. Washington, D.C.: National Council for the Social Studies. 
Bybee, R. W. (2009, January). The bscs 5e instructional model and 21st-century skills. A Commissioned Paper Prepared For A Workshop on Exploring the Intersection of Science Education and the Development of 21st-Century Skills.

Bybee, R. W. et al. (2006). The BSCS $5 E$ Instructional Model: Origins and Effectiveness. Colorado Springs, CO: BSCS.

Daniel, J. S. (1995). The mega-universities and the knowledge media: Implications of new technologies for large distance teaching universities. Unpublished master's Thesis, Concordia University.

Darmayanti, (2002). Kemauan belajar learning volition mahasiswa pendidikan jarak jauah studi kasus di Universitas Terbuka. Jurnal Pendidikan Terbuka dan Jarak Jauh, 3(1), 51-60.

Darmayanti, T. (2008). Efektivitas intervensi keterampilan self-regulated learning dan keteladanan dalam meningkatkan kemampuan belajar mandiri dan prestasi belajar mahasiswa pendidikan jarak jauh. Jurnal Pendidikan Terbuka dan Jarak Jauh. 9(2), 68-82.

Darmayanti, T. Rachmatini, M., Karim, F., \& Nurhayati, R. (2011). Studi jangka panjang tentang efektivitas intervensi psikologis dalam meningkatkan kemampuan belajar mandiri dan prestasi belajar mahasiswa pendidikan jarak jauh. Jurnal Pendidikan Terbuka dan Jarak Jauh. 12(1), 1-18.

Darmayanti, T., Setiani, M. Y., \& Oetojo, B. (2007). E-learning pada pendidikan jarak jauh: konsep yang mengubah metode pembelajaran di perguruan tinggi di Indonesia. Jurnal Pendidikan Terbuka dan Jarak Jauh, 8(2), 99-113.

Daulay, P. (2009). Pemanfaatan ict center dalam peningkatan akses sumber belajar bagi mahasiswa Universitas Terbuka, Jurnal Pendidikan Terbuka dan Jarak Jauh, 10(1), 18-29.

Diem, R. (1983). Technology and the social studies: Issues and responsibilities. Social Education, 4X(5), 308-310, 313.

Dillon, J., et al. (2006). The value of outdoor learning: Evidence from research in the UK and elsewhere. School Science Review, 87(320), 107-113.

Doolittle, P. E., \& David, H. (2003). Constructivism as a theoretical foundation for the use of technology in social studies. Theory \& Research in Social Education, 31(1), 72-104.

Hanafi, Julaeha, S., \& Noviyanti, M. (2008). The application of e-learning in tutorial process, Jurnal Pendidikan Terbuka dan Jarak Jauh, 9(1), 24-30.

Herman. (2013). The needs of collaboration in operating an open and distance learning institution: UT case. Jurnal Pendidikan, 14(1), 31-37. 
Huang, K-J., Lin, T-C., Graf, S., Lin, Y-C. (2008). Embedding mobile technology to outdoor natural science learning based on the 7e-learning cycle. Proceedings of World Conference on Educational Multimedia, Hypermedia and Telecommunications 2008, Chesapeake, VA: AACE.

Kadarko, W. (2000). Kemampuan belajar mandiri dan faktor-faktor psikososial yang mempengaruhinya: Kasus Universitas Terbuka. Jurnal Pendidikan Terbuka dan Jarak Jauh, 1(1), 18-28.

Karplus, R. (2003). Introductory physics: A model approach. New York: Captains Engineering Services.

Liu, T-C., Peng, H., Wu, W-H., \& Lin, M-S. (2009). The effects of mobile natural-science learning based on the 5e learning cycle: A case study. Educational Technology \& Society, 12(4), 344-358.

Martin-Hauser, L. (2002). Defining inquiry. The Science Teacher, 69 (2), 34-37.

Martorella, P. (1977). Interactive Technologies on the Social Studies: Emerging Issues and Applications. Albany: State University of New York Press.

NCSS. (2010). National Curriculum Standards for Social Studies: A Framework for Teaching, Learning, and Assessment. Silver Spring, MD: National Council for Social Studies.

Pokja Teknologi Informasi dan Komunikasi (TIK). (2006). Laporan hasil kunjungan kerja Universitas Terbuka. Jakarta: Kemendiknas.

Puspitasari, K. A. (2002). Layanan bantuan bagi mahasiswa Universitas Terbuka. In T. Belawati, dkk (eds). Pendidikan terbuka dan jarak jauh (pp. 315-333). Jakarta: Universitas Terbuka.

Puspitasari, K. A., \& Huda, N. (2000). Reviu hasil penelitian tentang tutorial di universitas terbuka. Jurnal Pendidikan Terbuka dan Jarak Jauh, 1(1), 28-35.

Puspitasari, K. A., \& Islam, S. (2003). Kesiapan belajar mandiri mahasiswa dan calon potensial mahasiswa pada pendidikan jarak jauh di Indonesia. Jurnal Pendidikan Terbuka dan Jarak Jauh. 4(1), 11-22.

Rafaeli, S., Ravid, G., \& Soroka, V. (2004, January 5-8). De-lurking in virtual communities: $A$ social communication network approach to measuring the effects of social and cultural capital. Proceedings of the $37^{\text {th }}$ Hawaii International Conference on System Sciences, Hawaii. 
Soroka, V., \& Rafaeli, S. (2006, May 23-26). Invisible Participants: How Cultural Capital Relates to Lurking Behavior. Proceedings on the International World Wide Web Conference Committee (IW3C2), Edinburgh, Scotland.

Speedy Wiki (2011). RT/RW-net. Retrieved February 12, 2014 from http://opensource.telkomspeedy.com/wiki/index.php/RT/RW-net

Sugilar. (2000). Kesiapan belajar mandiri peserta pendidikan jarak jauh. Jurnal Pendidikan Terbuka dan Jarak Jauh, 1(2), 1-8.

Sukarsih, Y. (2005). Pemanfaatan layanan online di institusi pendidikan jarak jauh, Jurnal Pendidikan Terbuka dan Jarak Jauh, 6(2), 69-76.

Teo, H.H., Chan, H.C., Wei, K.K., and Zhang, Z.J. (2003). Evaluating information accessibility and community adaptively features for sustaining virtual-learning communities, International Journal of Human-Computer Studies, 59(5), 671-697.

Thiagarajan, S., Semmel, D.S., \& Semmel, M. I. (1974). Instructional development for training teachers of expectional children. Minneapolis, Minnesota: Leadership Training Institute/Special Education, University of Minnesota.

UNDP-APDIP. (2011). Promoting ict for human development in Asia: Realizing the millennium development goals. India: Elsevier.

UT. (2012, September 7). Wamendikbud Resmikan 10 Gedung. Retrieved February 17, 2014 from http://www.ut.ac.id/berita

UT. (2014, February 2). Fasilitas Gratis "Teknologi Cloud" bagi Mahasiswa UT. Retrieved February 17, 2014 from http://www.ut.ac.id/berita

Windschitl, M. (2003). Inquiry projects in science teacher education: What can investigative experiences reveal about teacher thinking and eventual classroom practice? Science education, $87(1), 112-143$.

Yoenianto, A. (2013). 18.000 sekolah terkoneksi jaringan internet. Retrieved November 7, 2013 from http://daerah.sindonews.com 